VOICES FROM THE FIELD

\title{
The many manifestations of successful partnership
}

\author{
Editors: *Sarah Slates, Graduate School of Social Work and Social Research, \\ Bryn Mawr, College, USA, and Alison Cook-Sather, Education Program, Bryn Mawr College, \\ USA.
}

\begin{abstract}
Contributors: Meghan Allen, Ravanth Baskaran, Philippa Crombie, James Garo Derounian, Seb Dianati, Mike Dudson, Diane Grayson, Mian Arsam Haroon, Cath Fraser, Hannah Jardine, Amanda Millmore, Emmajane Milton, Yoko Mori, Alexandra Morgan, Jarett Vanz-Brian Pereira, Max Salman, Lauren Scharff, Jessie Storey, Kiu Sum, and Christopher C. Tisdell.
\end{abstract}

Contact: sslates@brynmawr.edu

This second iteration of Voices from the Field offers a selection of the many manifestations of successful partnership. Continuing the approach we, Sarah Slates (student coeditor) and Alison Cook-Sather (faculty co-editor), used in the pilot version of this new section of IJSaP, we dedicate this space to sharing a diversity of emerging ideas, opinions, and perspectives in the voices of the contributors, many of whom might not normally be represented within traditional forms of academic publishing and/or who do not have time for, or interest in, working through the peer-review process but who have something to say. We once again juxtapose authors' perspectives under categories that emerged from the contributions, and we present them with minimal editing, interpretation, or analysis so that the voices can speak for themselves, to one another, and with readers.

The prompt we offered for this issue was: What does successful partnership mean to you? One of the reasons we chose this prompt is that there is a danger in partnership work, as in higher education overall, of assuming a single or shared definition of success. Narrow definitions of success in partnership are especially challenged by students' perspectives that question, diverge from, and go beyond more traditional understandings of what success looks like in higher education more generally (Cook-Sather, 2018), as well as in partnership in particular (Cook-Sather \& Wilson, 2020). Our goal was to invite those who have experienced or who aspire to engage in partnership to map a wide range of definitions, both to affirm experiences participants have already had, and to encourage such multiplicity in definitions of success for setting goals for and assessing what is accomplished through partnership work. While many contributions affirm oft-cited definitions and principles of partnership (e.g., those offered in Cook-Sather et al., 2014, and Healey et al., 2014), the specific points and examples authors offer-both individually and juxtaposed to one another-illustrate the range of ways these definitions and principles can manifest and, perhaps, be differently defined. 
In response to the open invitation to the prompt above that we posted on the IJSaP website and on several international listservs, we received 18 responses from 20 authors, all first-time contributors to Voices from the Field. Since one of the goals of this section is to share the voices of a diversity of authors, we note the dimensions of diversity that authors indicated as part of their responses. Of the total of 20, six authors identify as students, nine as academic staff/faculty, one as professional staff, one as an administrator, two as faculty research coordinators, and one as both student and staff member. These authors are writing from within a range of institutional types in Australia, Canada, New Zealand, Pakistan, Singapore, South Africa, the United Kingdom, the United States, and Wales: six in a research-intensive context, seven in a context that strives to balance teaching and research, three in a teaching-intensive context, one at military academy, and one at the Society of Local Council Clerks/De Montfort University, England.

We once again invited contributors to name dimensions of their identities that they wanted highlighted, and we include that list of dimensions below. We recognize that any such list is partial, but we see mention of dimensions of identity that people choose to highlight as one of many necessary steps toward equity and inclusion. The dimensions of identity that authors shared include: academic and teacher educator committed to meaningful professional learning for all; cisgender white Canadian woman; computer science educator; doctoral researcher; educator by vocation; first-in-family Persian-Australian migrant who came to Australia as a refugee from Iran; Instructional Coach/Educational Developer; junior doctor working in the Singapore health system; longtime higher education (HE) teacher and community development practitioner; professor and director of a scholarship of teaching and learning program; Senior Director of Academic Affairs; student partner at University of Queensland; Waikato-Tainui, Whakatōhea; White female; and Year-4 Medical Student. Finally, in terms of previous publication experience, four authors indicated that they have published extensively, 10 that they have published some, and four that this was their first time publishing. We grouped contributions under the following loose and often overlapping categories of what successful partnership means to the authors of this collection of Voices from the Field:

- Promotes shared ownership, decision-making, and mutual benefits;

- Joins distinct but complementary perspectives and attends to the unique needs of partners;

- Pushes comfort zone, challenges norms, and asks new questions;

- Differentiates between process and outcome, which requires ongoing sustained work; and

- Promotes adaptability and responsiveness, particularly in response to the COVID-19 pandemic.

As with the set of submissions we received for the first iteration of Voices from the Field, the submissions received for this iteration are grouped to allow a story (one of many possible stories) to unfold through juxtaposition of voices rather than through analysis. We once again used shared Google Docs to further dialogue between contributors and co-editors. 
We invited all contributors and members of the Editorial Board to review drafts of Voices from the Field and provide feedback, and we worked to integrate all responses we received into the final version below.

SUCCESSFUL PARTNERSHIP PROMOTES SHARED OWNERSHIP, DECISION-MAKING, AND MUTUAL BENEFITS

Teamwork, collaboration, and flexibility are all essential components of any partnership. As we embarked on the journey of setting up a medical revision community, under the banner of OSCEazy [a name built on the Objective Structured Clinical Examination], partnership played a central role. We needed sponsors to partner, medical professionals to help us review and teach, as well as organizations to support us with administrative tools. All these partnerships were possible as we shared a common goal of increasing accessibility to free medical education to students and healthcare professionals around the globe. Another component of any partnership is a symbiotic and mutual partnership. It is seldom mentioned, but from our experience it is the key to a successful partnership.

-Ravanth Baskaran, student, Cardiff University School of Medicine, Wales, United

Kingdom

It is challenging to implement Students as Partners ( $\mathrm{SaP}$ ) in medicine due to its hierarchical structure and inherently imbalanced student-staff power dynamics. As a medical student, I had the privilege of working with senior clinicians to spearhead a SaP initiative to reform the Year-3 medical curriculum. Critical to success was the clear establishment of joint ownership. Shared ownership did not imply a complete overhaul of medical hierarchy, because mutual trust and respect were essential for its implementation. Instead, there was recognition that both students and staff have access to unique resources and skillsets that could be collectively applied to the project. Senior clinicians possessed invaluable experience and knowledge, ensuring content accuracy and relevance. Students provided "outside perspectives" on effectiveness of content delivery, while having real-time access to raw, truthful feedback from peers facilitated consistent project improvements. The students' evolution from "customer" to "coorchestrator" was truly empowering and maximised student-staff engagement.

-Jarett Vanz-Brian Pereira, student, The University of New South Wales, Sydney Australia (where the SaP initiative was carried out), currently working in Singapore

Undergraduate Bachelor of Sport and Recreation students are preparing to enter a profession where they will be personal trainers, coaches, fitness and wellness rolemodels, and leaders. Students-as-Partners is an ethos which is deeply embedded in our teaching and learning ideology, as we aim to build the skills and mindset of work-ready graduates confident in their ability to inspire and champion others' achievements. Building a successful partnership with students means sharing power and decisionmaking wherever possible: a key example is the third-year students' industry-based 
research project. With classroom sessions and scaffolded support, students select their own topics, develop their own professional relationships, write proposals and complete approval processes, gather, collate and analyse data, and present it to academic and industry audiences. Students tell us that the substantive interaction with their researchplacement organisation and often the wider industry is often one of their most significant learning experiences in the entire degree.

-Mike Dudson, academic staff/faculty, Sport and Recreation Lecturer, Toi Ohomai Institute of Technology, New Zealand

With a large team of student teaching assistant colleagues, I teach first-year courses that are taken by students from across the university. I believe that successful partnership requires trust, all participants truly listening to each other, and shared decision-making. As educators, we are often used to making all the decisions about our curriculum and pedagogy, so surrendering control and power can be difficult. My challenge for educators who want to further their relationships and partnerships with students is to take a course. The experience of being in a classroom rather than at the front of a classroom provided me opportunities to reflect on my practices, to reconsider how I might further foster my working relationships with students, and to think about how I can continue to learn with and from students.

- Meghan Allen, academic staff/faculty, University of British Columbia, Canada

\section{JOINS DISTINCT BUT COMPLEMENTARY PERSPECTIVES AND ATTENDS TO THE UNIQUE NEEDS OF PARTNERS}

To me, successful partnership means understanding that all partners, both students and staff, are in different phases of life and will have different needs and requirements. I have been a student partner for 2 years and have worked with various staff partners over that time. Staff are generally very understanding that students have many competing responsibilities (such as part-time work, internships, etc.), but I find partnership is most successful when students are also considerate of the staff experience. Small things, such as ensuring the bulk of correspondence takes place during "office hours," can ensure mutual respect and understanding from all partners.

-Jessie Storey, student, University of Queensland, Australia

To me, a partnership implies meaningful contributions from all individuals/entities involved, without which the overall effort might not be successful. In 2016 we began a partnership effort between the Scholarship of Teaching and Learning (SoTL) Program and our students to promote student use of higher efficacy learning strategies. Each year about a dozen students become certified members of a science of learning team and lead seminars to help their peers who are struggling academically. The students are key partners - they have "street credibility" with their peers and knowledge of student life that allows us to more effectively design and schedule our seminars and other 
efforts. The SoTL Program provides science of learning training and mentorship for the team and continuity for the efforts. Without a doubt, both are needed for success.

- Lauren Scharff, academic staff/faculty, U.S. Air Force Academy, United States

Disclaimer: The views expressed are those of the author and do not necessarily reflect the official policy or position of the Department of the Air Force, the Department of Defense, or the U.S. government. PA\#: USAFA-DF-2021-255

Successful partnership is a synergetic and dynamic relationship of participants within the academic landscape that has reached equilibrium. Variables such as power, collaboration, collegiality, trust, credibility, and expectations must focus on the result that best enhances the student experience in learning and the teacher experience in teaching. Partnership will only live up to its truest meaning when there is an explicit necessity for one another (learner/instructor relationship) within the academic landscape. Students need instructors to disseminate knowledge and communicate it effectively, and teachers need to effectively communicate content in a manner that is digestible to the students. This can only be achieved when students and teachers can confidently and respectfully communicate their wants and needs as those pertain to the academic transfer and sharing of knowledge. Reconciling power differentials is a good start, but a "togetherness" in partnership is significantly important when considering the Students-as-Partners framework.

-Max Salman, student and staff, McMaster University, Canada

\section{PUSHES COMFORT ZONE, CHALLENGES NORMS, ASKS NEW QUESTIONS}

A successful partnership is an unexpected surprise. It is an experience that leaves the students, staff, and faculty involved amazed by how much they have grown and all that they have accomplished together. In my role as an educational developer, I have partnered with students to bring the student voice into teaching-center programming, and I have also encouraged and facilitated student-faculty partnerships focused on student-centered course design and implementation. No matter how often I engage in partnership with students myself, I am always astounded by what grows out of the conversation and collaboration. I am thrilled by how often I hear the students and instructors I work with make statements like, "I can't believe how much I learned from engaging in this partnership" or "I could never have imagined what this partnership would bring." I challenge us to let partnership surprise us again and again.

-Hannah Jardine, professional staff, The Catholic University of America, United States

A successful partnership is all about having an impactful yet understanding relationship between staff and students, considering each other's values and beliefs for a shared vision. To have your voice heard as a student, especially as an ethnic minority individual, is rewarding. Seeing how a senior individual values your mere idea and channels it into your institutional practices highlights how powerful your student position can be. 
Partnership projects develop my graduate attributes, pushing me out of my comfort zone to learn and engage in wider scholarly activities outside academia. They challenge me to think about my possible aspirations inspired by staff whom I have worked with. Despite the perception of possible unhealthy power dynamics in a partnership, such as tensions and challenges, my partnership experience highlights how the process of engagement underpins the outcomes, empowering and enhancing our sense of belonging no matter who we are.

$$
\text { -Kiu Sum, student, University of Westminster, United Kingdom }
$$

To me, a successful partnership means paying respect to each other's ideas. I learned the concept of Students as Partners (SaP) in my first year of my doctoral program in New Zealand where I am currently studying academic development (AD) in higher education. Until then, I had never imagined a teacher-student relationship as "partnership" - especially coming from an East Asian educational background. Like in many other East Asian countries, our Japanese education is embedded in Confucian philosophy with the authoritative role of the teacher virtually fixed as "Sensei" (teacher), who we, students, look up to. Though the positioning of teachers contrasts to what the emerging SaP implies - with an image of a somewhat equal relationship - I find the underlying philosophy of respect for each other's ideas to be the same. In both cases, the teacher builds his/her teachings upon feedback from students which I believe is the essence of the SaP concept: co-creation of knowledge.

\section{-Yoko Mori, student, University of Otago, New Zealand}

I am a teaching academic and community development practitioner. Fundamentally, a true partnership between academic and student must be based on equality and integrity. Each of these facets should relate to both the process and product of collaboration (Ellis et al., 2011; McLuhan, 1964). In other words, the research or teaching focus, methodology, inputs, interpretation, outputs, and credit must fully involve, acknowledge, and reward student and staff. This recognition demands an assetbased approach (Pitchford, 2018) as opposed to the commonplace deficit model whereby students are found wanting. Here is an opportunity to acknowledge and harness the knowledge, skills, and capabilities of each partner, thereby overcoming the innate inequality and power dynamic of academic first, student following.

$$
\text { -James Garo Derounian, academic staff/faculty, Society of Local Council Clerks/De }
$$

Montfort University, England, United Kingdom

Successful student partnership moves away from the methodical forms of education towards one concerned with change, starting with the question "Why?" From this position, the collective "why?" is where successful partnership begins. "Why are we expected to learn this way?," "Why are we assessed like this?," and "Why does the institution provide support in this particular way?" Once staff and students search for a better "why," we start to change the way we view the purpose of the classroom, the 
teacher, and the student. These questions not only form the successful ingredients for successful partnership, but they have also become the bedrock of all initial student partnership discourse. Successful partnership in teaching and learning should focus on at least one or more of the devised nine-step framework: (a) learning objectives, (b) assessment, (c) learning activities, (d) technology, (e) hybrid/flexibility, (f) instructional design, (g) learning resources, (h) learning support, and (i) evaluation.

-Seb Dianati, academic staff/faculty, University of Queensland, Australia

There aren't many occasions in academic life when master's and doctoral students feel more vulnerable than during the proposal submission and review process. In our institute, postgraduate students (a) develop a project with their supervisor, (b) "pitch" it to a panel of their supervisor's colleagues, (c) submit it to a researchers' community of practice (CoP) for multi-disciplinary formative critique, (d) have revisions overseen by supervisor and CoP Chair, and finally, (e) it gets to our Human Ethics and Research Committee. Exhausting! In the Research Office, we often wonder how far the final project has deviated from the student's original interest. Of course, we're all tasked with helping students develop valid projects with robust methodologies, but maybe this could be done a little more with, rather than for (or to), them? Our view, then, is that a successful SaP mindset at the research approval table invites students' attendance, includes their membership, and welcomes their voices.

- Cath Fraser and Philippa Crombie, Faculty Research Coordinators, Toi Ohomai,

New Zealand

\section{DIFFERENTIATES BETWEEN PROCESS AND OUTCOME, WHICH REQUIRES ONGOING SUSTAINED WORK}

An effective partnership between two people is similar to the relationship between a rocket and its booster. They are both working towards some goal (the mission), and each can provide support and direction to each other in making progress towards the goal. Much like space travel, partnerships have the power to explore new horizons and move beyond the limitations of individual capabilities. The successes associated with the outcomes of partnership are shared. However, a partnership is much more than just helping to achieve some shared goal. Seeing your partnership as a process is also important. The partnership process can be a voyage into the partially unknown-a structured, incremental progression through a process of reflection, growth, and discovery. As a partner you can positively transform the lives of all involved and develop an altered state of being in your partner, yourself, and your institutions.

-Christopher C. Tisdell, Professor, The University of New South Wales and The University of Queensland, Australia

Engaging with students as partners in higher education is too often rushed, superficial, and tokenistic. Working authentically with students as partners cannot exist as a discrete or tick-box exercise-as it results in it feeling fake and disingenuous. Genuine 
partnership working requires a sustained commitment to the careful relationshipbuilding that is central to all good pedagogical practice. Whilst all this requires dedicated time and effort, it has the potential to empower students and better equips them to learn from their own educational experiences-promoting greater engagement and academic success. Embracing students as collaborators and change-agents allows HE educators to explore teaching and learning experiences from alternate perspectives and to engage in possibility thinking about these. Working honestly and openly with students as partners always results in rich, contextualised professional learning opportunities for educators, regardless of discipline, and can be a valuable feature of professional learning for all who teach in higher education.

-Emmajane Milton and Alexandra Morgan, academic staff/faculty, Cardiff

University, Wales

As a teaching-intensive academic, I have initiated a number of partnerships. Our success is measured not so much in the output of each partnership (although that is important, and it is good to have something tangible to show for our work) but in the feelings of community that are engendered as a result of partnership working. Students become partners altruistically, often because they want to be heard and make a difference, and success can be seen by the way that they engage and encourage others to engage with the focus of our projects. With each partnership I feel as though there are more students wanting to get involved and that each partnership stands on the shoulders of the previous one, success breeding success. I suppose that ultimately the success is in creating a community or culture where student partnership is the norm and is celebrated and where that culture encourages enthusiastic participation.

-Amanda Millmore, academic staff/faculty, University of Reading, United Kingdom

PROMOTES ADAPTABILITY AND RESPONSIVENESS, PARTICULARLY IN RESPONSE TO THE COVID19 PANDEMIC

As a medical student in a South Asian country, university life revolves around completing the curriculum and its associated objectives. This dogma was questioned when I chose to participate in partnering with the Aga Khan University's blended and digital learning team to design an orientation session for all incoming freshmen in 2021. Due to the pandemic, this was the first time the university would be holding an orientation completely online and would focus on each student's digital presence and responsibilities. Asking me and my fellow teammates to take the lead in creating the orientation and acknowledging us as the primary stakeholders was the first step among many to culminate in a successful execution. Understanding student and faculty perspectives along with transparency and continuous mentorship formed the keystones of my experience in this project and are unironically ubiquitous hallmarks of a successful partnership.

- Mian Arsam Haroon, student, Aga Khan University, Pakistan

Suggested citation format: [Contributor last name, contributor first name]. (2021). [Title of subsection of Voices 228 from the Field]. In S. Slates \& A. Cook-Sather (Eds.,) The many manifestations of successful partnership. 
When COVID-19 struck and South Africa went into lockdown in March 2020, we moved all teaching online by creating sites for all courses on our learning management system (LMS). Sadly, our LMS buckled when usage was high. We had been planning to acquire a more modern LMS for some time, but our 2020 experience spurred us on. On 24 December we signed the contract to acquire Canvas. Online classes were due to start 8 March, giving us 2 months to change over. In addition to a massive training programme for academics and learning designers, students helped design and publicise an LMS student training site, made a cool video on how to access and log in to the new LMS, helped train other students, and provided online peer support.

\section{-Diane Grayson, Administrator, University of the Witwatersrand, South Africa}

\section{CONCLUSION}

The contributions in this edition of Voices from the Field invite readers to consider and reconsider notions of success, both affirming notions of success articulated in ongoing conversations in the literature and adding new insights. Contributors argue that successful partnership requires shared ownership of goals and decision-making processes. Shared ownership requires careful listening to build trust, respect, and understanding, all of which require sharing power. These assertions remind us that partnership does not mean that everyone contributes the same thing-one of the most basic definitions of partnership (CookSather et al., 2014); rather, it means that everyone has an important-often different-and valued contribution to make. According to these contributors, success has to do with mindset and modes of engagement, and when partnership is truly shared, so too are the many benefits.

Contributors also argue that successful partnership brings together and honors the various perspectives, strengths, and needs of partners. Indeed, these differences are both what define partnership and make it so potentially generative, but that potential can only be realized if partners see the differences as strengths and practice empathy. The deeply relationalmessy, human, negotiated, in process - work of partnership can make it successful, but only if, as authors of other reflections on successful partnership have noted (Cook-Sather, 2015; Ostrowdun et al., 2020), participants are vigilant about embracing differences as sources of understanding and growth.

Relatedly, meaningful partnership often requires a willingness to push beyond one's comfort zone, challenge norms (especially deficit-based models), and ask new questions. It creates opportunities for new ways of thinking and practicing through being receptive to what you are not familiar with and what you do not already know. Naming the productive discomfort such dynamics cause is an important aspect of recognizing these dimensions as reflective of success, not failure. Relatedly, it is possible to find ways of interpreting seeming tensions and conflicts, such as cultural differences, as opportunities for ongoing development and expansions of understanding of partnership (see Chng, 2019; Eze, 2019; Cook-Sather et al., 2021, forthcoming). Respecting all partners' ideas while also asking "why?" is a manifestation of success in partnership because both make the most of multiple perspectives and sustain a 
growth mindset, which has been found to support the development of partnership work (CookSather et al., 2020).

Partnership is an ongoing process, not a single static outcome, as others have also argued (Cook-Sather et al., 2019; Matthews, 2017). It requires continued commitment to community and cultural change as and through working together. Such a notion and practice are often in tension with the goal- and evaluation-focused work in higher education, so partnership work requires focused attention and-in some cases, resistance-to sustain. Contributors argue that a focus on relationships, process, and community, rather than only on outcomes, is another manifestation of successful partnership.

The manifestations of successful partnership noted above might appear under any circumstances. Over the last 2 years, successful partnership has been both affirmed and redefined (Ntem et al., 2020). Specifically, partnership work contributed to successful navigation of the rapid transition to remote learning during the COVID-19 pandemic, perhaps offering us lessons, as others suggest (Cook-Sather, 2021; Healey \& Healey, 2020; Weiler \& Williamson, 2020; Labridy-Stofle, 2020), that we can take forward into post-pandemic times.

\section{REFERENCES}

Chng, H. H. (2019). The possibilities of students as partners-A perspective from Singapore. Teaching and Learning Together in Higher Education, 1(27). https://repository.brynmawr.edu/tlthe/vol1/iss27/3/

Cook-Sather, A. (2015). Dialogue across differences of position, perspective, and identity: Reflective practice in/on a student-faculty pedagogical partnership program. Teachers College Record, 117(2). https://www.tcrecord.org/content.asp?contentid=17784

Cook-Sather, A. (2018). Listening to equity-seeking perspectives: How students' experiences of pedagogical partnership can inform wider discussions of student success. Higher Education Research and Development, 37( 5), 923-936. https://doi.org/10.1080/07294360.2018.1457629

Cook-Sather, A. (2021). Responding to twin pandemics: Reconceptualizing assessment practices for equity and justice. Research \& Practice in Assessment, 16(2), 5-16. https://www.rpajournal.com/dev/wp-content/uploads/2021/08/Responding-to-TwinPandemics-RPA.pdf

Cook-Sather, A., Bahti, M., \& Ntem, A. (2019). Pedagogical partnerships: A how-to guide for faculty, students, and academic developers in higher education. Elon University Center for Engaged Teaching Open Access Series. doi.org/10.36284/celelon.oa1

Cook-Sather, A., Bovill, C., \& Felten, P. (2014). Engaging students as partners in learning \& teaching: A guide for faculty. Jossey-Bass. 
Cook-Sather, A., Gauthier, L., \& Foster, M. (2020). The role of growth mindset in developing pedagogical partnership programs: Findings from a cross-institutional study. Journal of Innovation, Partnership and Change, 6(1). http://dx.doi.org/10.21100/jeipc.v6i1.1004

Cook-Sather, A., Ho, L., Kaur, A., \& Tamim, T. (2021, forthcoming). Translating pedagogical partnership in/to academic staff development in the global south.

Cook-Sather, A., \& Wilson C. (Eds.) (2020). Building courage, confidence, and capacity in learning and teaching through student-faculty partnership: Stories from across contexts and arenas of practice. Lexington Books.

Ellis, C., Adams, T. E., \& Bochner, A. P. (2011). Autoethnography: An overview. Forum: Qualitative Social Research, 12(1), Art. 10. https://www.ssoar.info/ssoar/bitstream/handle/document/36323/ssoar-hsr-2011-4ellis et al-Autoethnography an overview.pdf

Eze, A. (2019). From listening to responding to reading: Building capacity through four pedagogical partnerships. Teaching and Learning Together in Higher Education, 1(26). https://repository.brynmawr.edu/tthe/vol1/iss26/2

Healey, M., \& Healey, R. (2020, September 2). Promoting pandemic partnerships [Webinar]. Healy HE consultants. https://www.healeyheconsultants.co.uk/pandemic-partnerships

Healey, M., Flint, A., \& Harrington, A. (2014). Engagement through partnership: Students as partners in learning and teaching in higher education. Higher Education Academy.

Labridy-Stofle, C. (2020). Uprooted rhizomes: Collaborating in times of troubling transitions. Teaching and Learning Together in Higher Education, 1(30). https://repository.brynmawr.edu/tthe/vol1/iss30/4

Matthews, K. E. (2017). Five propositions for genuine students as partners practice. International Journal for Students as Partners, 1(2). https://doi.org/10.15173/ijsap.v1i2.3315

McLuhan, M. (1964). Understanding media: The extensions of man. McGraw-Hill.

Ntem, A., Nguyen, E., Rafferty, C., Kwan, C., \& Benlahcene, A. (2020). Students as partners in crisis? Student co-editors' perspectives on COVID-19, values, and the shift to virtual spaces. International Journal for Students as Partners, 4(2), 1-8. https://doi.org/10.15173/ijsap.v4i2.4432 
Ostrowdun, C., Friendly, R., Matthews, K., de Bie, A., \& Roelofs, F. (2020). Holding space and engaging with difference: Navigating the personal theories we carry into our pedagogical partnership practices. International Journal for Students as Partners, 4(1), 82-98. https://doi.org/10.15173/ijsap.v4i1.4093

Pitchford, A. (2018, September 28). There is no community at university. WONKHE. https://wonkhe.com/blogs/there-is-no-community-at-university/

Weiler, K., \& Williamson, A. (2020). Partnering to build responsive learning communities that support students in crisis. Teaching and Learning Together in Higher Education, 1(30). https://repository.brynmawr.edu/tlthe/vol1/iss30/3 